\title{
Organizational Citizenship Behavior (OCB) Variable on Employees Of PT. Smartfren Jember
}

\section{Triane Wahyu Lestari*}

Post Graduate of Master Management High School of Economics Mandala Jember

\section{A R T I C L E I N F O}

Article history:

Received 25 August 2018

Received in revised form

02 October 2018

Accepted 20 October 2018

Available online 29

November 2018

Keywords:

job satisfaction,

organizational culture,

motivation, organizational

commitment and OCB

\section{A B S T R A CT}

This study aims to examine and analyze empirically the influence of job satisfaction, organizational culture, motivation and organizational commitment to OCB on employees of PT. Smartfren Jember. This research was conducted on employees of PT. Smartfren Jember. The research population was employees of PT. Smartfren Jember numbered 120 people. The sampling technique used in this study is proportional sampling. The numbers of samples of this study were 50 people scattered in all parts of PT. Smartfren Jember. Data analysis method uses multiple linear regression. The results showed that 1) Job satisfaction had a positive effect through OCB on employees of PT. Smartfren Jember; 2) Organizational Culture has a positive effect through OCB on employees of PT. Smartfren Jember; 3) Motivation has a positive effect through OCB on employees of PT. Smartfren Jember; 4) Organizational commitment has a positive effect through OCB on employees of PT. Smartfren Jember; 5) Job satisfaction, organizational culture, motivation, organizational commitment simultaneously have a positive effect through OCB on employees of PT. Smartfren Jember.

\footnotetext{
* Corresponding author.

E-mail addresses: anewahyulestari@gmail.com (Triane Wahyu Lestari),
} 


\section{Introduction}

OCB plays role to change the atmosphere of a formal organization to be a little relaxed and full of cooperation. It is expected that with such an atmosphere, the tension between employees can be reduced and because of the supportive atmosphere, it is expected that employee productivity will increase, so that efficiency will be achieved. This is also justified by Smith et al. (1983) which revealed that OCB can smoothen and facilitate social life in an organization and support the company's performance by launching corporate social activities.

One of the most important factors to form OCB is job satisfaction. The statement is very logical since satisfaction is the main determinant of OCB on employees (Robbins, 2006). Satisfied employees are more likely to speak positively about the organization, tend to help coworkers, and make their job performance beyond normal estimation. Moreover, satisfied employees may be more obedient to the call of duty, because they want to repeat their positive experiences. Organ and Bateman (1988) confirm that all dimensions of satisfaction such as work, co-worker, supervision, promotions, pay and overall are positively collaborating with OCB.

Another factor that plays a role in shaping OCB on employees is organizational commitment. According to organizational commitment is a situation in which an employee siding with a particular organization and its goals and desires to maintain membership in the organization. So, high job involvement means taking part in an individual's particular job, while high organizational commitment means taking sides with the organization that recruits the individual. Whereas according toorganizational commitment is an attitude that reflects the extent to which an individual knows and is bound to his organization. An individual who has a high commitment is likely to see himself as a true member of the organization. Organizational culture forms OCB. claims that implementation of organizational culture can improve OCB, while states that organizational culture can improve employees' OCB behavior. It can be said the better the organizational culture, the higher the OCB on employees.

This research departs from a concept of the importance of OCB. OCB is a behavior that is not related to an organization's formal reward system, individual choices and initiatives, but in aggregate increases organizational effectiveness, helps to change the atmosphere of a formal organization to be a little relaxed and full of cooperation. Based on the results of preliminary observations, with the high level of Organizational Citizenship Behavior, employees will easily help others or have altruism behavior, prioritize the public interest, be careful in conscience, promote unity and sportsmanship. However, in fact at PT. Smartfren Jember, the overall OCB behavior has not reached its maximum level. There are still many employees who only read newspapers during working hours, do small talk/chit-chat to others, and leave work hours for personal use. In addition, there are still many employees who do not have the will to work hard. They laze around, even many employees who go home instead of stay at office work hours. It is also found the employees who are wandering around working hours. Indeed, it has an impact on the level of absenteeism on office session or meetings.

As one of the telecommunication companies in Indonesia, PT. Smartfren Jember should have employees who must be reliable and want to contribute more to the company. Employees are required to be able to achieve the targets set by the company and must be able to get over with daily works. Employees must also be orderly with their attendance. In addition, it is not uncommon to see employees who are still remain at office to complete several jobs when work hours are over even on Saturday there are several employees who still come to the office to work. The employees of PT. Smartfren Jember do not only serve customers and also marketing their products but their coverage area is handling all customers in Jember. Employees are not easy to control and serve customers who use providers and products produced by PT. Smartfren Jember because it requires good coordination between teams so that any constraints or complaints that are addressed by customers can also be resolved well and the marketing of their products can be accepted by the Jember community. The purpose of this study is as follows to test and analyze empirically the influence of job satisfaction, organizational culture, motivation and organizational commitment to OCB both simultaneously and partially on employees of PT. Smartfren Jember

\section{Methods}

The approach used in this study is a quantitative approach (positivism). Quantitative approach bases the study on the rational principle of empirical. This type of research is an explanatory research type. This study intends to explain the influence between variables through testing hypotheses and at the same time explaining some variables. The research was conducted at PT. Smartfren Jember at Jalan Majapahit No. 6 Jember. 
The population in this study was employees of PT. Smartfren Jember in amount of 120 people. The sampling technique used in this study is proportional sampling. Based on the proportional sampling process, the sample is explained by a sample of 50 people divided into 3 parts, namely gallery, distributor and network, which is calculated proportionally per sample. Gallery section with a total population of 30 employees, the sample chosen was 12 employees from a total sample of 50 people. Distributor section with a total population of 50 employees, the selected sample was 21 employees from a total sample of 50 people. Network section with a total population of 40 employees, the selected sample was 17 employees from the total sample total of 50 people. Based on the calculation of the sample, the numbers of samples of this study were 50 people scattered in all sections of PT. Smartfren Jember.

The research variable is explained by the dependent variable, namely Job Satisfaction (X1) developed by Locke in which consists of five dimensions of work, namely (1) The work itself, in which the work provides an interesting task, the opportunity to learn and the opportunity to accept responsibility; (2) Salary, a number of wages received and the rate at which this can be seen as something that is considered appropriate compared to others in the organization; (3) Promotional opportunities, opportunities to advance in organizations; (4) Supervision, the ability of supervisors to provide technical assistance and behavioral support; (5) Co-workers, the degree to which coworkers are technically savvy and socially supportive.

Organizational culture (X2) is measured by indicators used to measure organizational culture variables namely Innovation and risk taking, Attention to detail, Outcome orientation, People orientation, Team orientation, Aggrecivenes, and Stability.

Motivation (X3) is an encouragement from the employee either from inside or outside to increase OCB. Motivational variables are measured using indicators according to namely achievement, responsibility, self-development, supervision and status.

Organizational commitment (X4) is a deep willingness of employees to carry out all things related to organizational performance. The indicators used to measure are based on theory, including affective organizational commitment, normative organizational commitment and ongoing organizational commitment.

OCB is the behavior of company employees which is intended to improve the effectiveness of company performance without ignoring individual employee productivity goals according to the indicators of OCB, namely Conscientiousness, Sportmanship, Courtessy, Altruism, Civic Virtue, Peacekeeping, Cheerleading.

The distribution of the questionnaire with the Likert scale was designed to allow the questionnaire to be filled in properly and returned. The scale form in the closed questionnaire used in this study uses a Likert scale with a standard scale of 1 to 5 . Data analysis method using the test Validity with validity criteria performed by factor analysis (Confimatory Factor Analysis) is valid if the KMO value> 0.6 and Barlett's Test with a significance of $<0.05$ and the component loading each indicator $>0,60$ and reliability test by calculating Cronbach Alpha. After assessing alpha, then it was continued by comparing the value with the critical number of reliability. The instrument used in the variable is known to be reliable (reliable) if it has a Cronbach Alpha> 0.60 .

Tested multiple determination coefficient (R2) can decrease if a new variable is added to the regression model (even if R2 increases). However, the increase in R2 does not mean that the new variables entered are statistically significant.

Testing the hypothesis using the F test with criteria if Fcount> Ftable then Ho is rejected and Ha is accepted, meaning all independent variables together are a significant explanatory to the dependent variable and if Fcount $<$ Ftable then Ho is accepted and Ha is rejected, meaning all independent variables are together is not a significant explanatory variable on the dependent variable.

Partial testing (t-test) is testing the regression coefficients individually by determining the statistical formula that will be tested with the testing criteria where 1) thitung>ttable Ho is rejected and $\mathrm{Ha}$ is accepted, meaning that there is an influence between the independent variables on the dependent variable with the degree of confidence used equal to $\alpha=5 \%$ and tcount $<$ ttable Ho is accepted and Ha is rejected, meaning there is no influence between independent variables on the dependent variable with the degree of confidence used is $\alpha=5 \%$.

\section{Result and Discussion}

The results of the analysis of respondents showed that the number of female respondents was almost double compared to the number of male respondents, where women were 35 people $(70 \%)$ and men as many as 15 people (30\%). The large number of women resulting from the hiring of employees so far is that more women are caused more. Based on the education level, the most respondents were 
Bachelor's degree (S-1), in amount of 30 people or $60 \%$. This is a policy that is applied at the time of recruitment which is based on thinking on the ability of the institution in welfare issues. Even so, with S-1 degree of education background, these employees continue to be upgraded by including various trainings and giving opportunities to attend higher education related to their respective fields of work. In addition to the existence of employee with S-2 degree of education as much as 1 person or 2\%, PT. Smartfren Jember also continues to pay attention to employees who occupy leadership positions or those who are recruited / prepared to occupy leadership positions. This can be seen by the number of employees with DIII education as many as 7 people or $14 \%$.

Based on test resut of F-test, it is known the significance of $\mathrm{F}$ count of 0.025 is less than the significance level of $5 \%(0.000<0.05)$ then reject Ho and accept Ha. This means that job satisfaction, organizational culture, motivation and organizational commitment simultaneously have an influence on OCB.

It can simultaneously be seen from the value of Adjusted R Square (R2) that it shows the percentage of influence of all independent variables on the dependent variable, where the closer to the value 1 , the greater the influence of all independent variables on the dependent variable. Based on the results of multiple regression analysis, it can be seen the value of Adjusted R Square (R2) which is 0.537. This shows that $53.7 \%$ of OCB level variables can be explained by independent variables, while the remaining $46.3 \%$ is influenced by other variables outside the variables used.

Motivation factors, job satisfaction, OCB and employee performance are important in an organization, because many studies show that organizational culture and employee job satisfaction are associated with the improvement of employee performance. Based on the previous data analysis, it can be seen that several factors of human resources include motivation and job satisfaction affect the role of OCB on employees and employees performance at PT. Smartfren Jember. These results are also supported by the results of respondents' answers to factors of job satisfaction, organizational culture, motivation and commitment to OCB on employees of PT. Smartfren Jember. The results of the study are explained in the following sub-chapters:

a. Effect of Job Satisfaction Factors through OCB on Employees of PT. Smartfren Jember

When there is a high quality job satisfaction, the employer will have a positive view on his subordinates so that his subordinates will feel that his boss gives a lot of support and motivation. In contrary, if job satisfaction is at low quality, then the employer will pay less attention to his subordinates. In addition, the employer himself will have a negative view of his subordinates and his subordinates also respond by showing lack respect and trust in their superiors.

Based on the calculation of multiple linear regression analysis, job satisfaction has a significant effect on OCB. In this study, it can be seen that the direct influence of the job satisfaction factor through OCB on employees of PT. Smartfren Jember proved to be significant. This means that the first hypothesis which states that job satisfaction has a significant effect on OCB is proven.

A very strong OCB by employees of PT. Smartfren Jember can be shown by the results of the analysis of the distribution of respondents' answers related to OCB. It can be seen that OCB is a value or norm that serves as a guide for employees to do their work. OCB behavioral results indicate that employees of PT. Smartfren Jember have a behavior that always prioritizes the progress of employees of PT. Smartfren Jember by maintaining good relationships with colleagues to avoid interpersonal problems. Employees who have this dimension are people who respect and care for others. These behaviors describe "employee added value" which is one form of prosocial behavior, namely positive, constructive and meaningful social behavior.

b. Effect of Organizational Culture Factors through OCB on Employees of PT. Smartfren Jember

There is an influence of organizational culture on OCB. It explains the application of cultural values in organizations directly leads to increased OCB behavior. This is because the organizational culture at PT. Smartfren Jember which is an institution that has long been established and has a strong culture embedded with its employees. When organizational culture begins to shape, various practices can help socialize the acceptance of core values and ensure that the culture is maintained. The practice can explain the steps of socialization, including compliance with important organizational values. Identification with these values helps employees to reconcile their personal sacrifices as a separate job satisfaction to be accepted as an employee of the organization. Employees learn to accept these values and believe that their organization does not do anything that will harm them and lead to OCB behavior.

The success of PT. Smartfren Jember in implementing organizational culture among employees will influence every employee's positive actions and behavior, both in-role behavior and extra-role behavior and will also deliver PT. Smartfren Jember on success with satisfaction. Organizational culture readiness is needed to be able to absorb discretionary behavior from its employees. Employees who feel that the organizational culture at PT. Smartfren Jember supports every individual value or goal they will be more 
comfortable with PT. Smartfren Jember so that employees will support every plan of PT. Smartfren Jember and the possibility of showing behaviors that are outside the job description are also getting stronger with the existence of job satisfaction that will be achieved.

c. The Effect of Motivation Factors through OCB on Employees of PT. Smartfren Jember

Motivation is an encouragement that arises is a contribution to OCB. Based on the calculation of multiple linear regression analysis, motivation has a significant effect on OCB. In this study, there was a direct effect of motivational factors through OCB on employees of PT. Smartfren Jember proved to be significant. This means that the first hypothesis that states motivation has a significant effect on OCB is proven. Based on the results of the assessment of respondents, the motivation that is perceived well by employees and motivation has a significant effect through OCB on employees. This is due to the motivation that affects employees of PT. Smartfren Jember is done well so it will cause good performance for employees.

Implementation of research results of PT. Smartfren Jember is manifested in a variety of different jobs for all types of work and employee distress in doing the work. It makes different motivation leads to different OCB. Work in the field of telecommunication has caused employees in this field to tend to be innovative, to have a lot of new thinking and to develop the results of PT. Smartfren Jember.

d. Effect of Organizational Commitment to OCB at PT. Smartfren Jember

The results showed that organizational commitment had a positive and significant effect on OCB. Thus the hypothesis which states that commitment has a significant effect is accepted. Because employees feel they have an emotional attachment to their organization, and are willing to spend the rest of their careers in the organization and employees have a strong sense of belonging to the organization.

Organizational commitment at PT. Smartfren Jember can be shown by the presence of several things that are perceived, experienced, felt and thought by respondents. Based on the results of the analysis of the distribution of respondents' answers related to commitment, it can be seen that with the commitment to make employees have a hard business and willingness and directed towards achieving the results of the agency and the attitude of loyalty to the agency.

\section{Conclusion}

Based on the results of the study, it can be concluded the following matters: 1) Job satisfaction has a positive effect through OCB on employees of PT. Smartfren Jember. By experiencing high quality job satisfaction, a boss will have a positive view of his subordinates so that his subordinates will feel that his boss gives a lot of support and motivation; 2) Organizational Culture has a positive effect through OCB on employees of PT. Smartfren Jember because it gives attention and provides a lot of support so that OCB increases; 3) Motivation has a positive effect on OCB of employees of PT. Smartfren Jember. This is due to the motivation of employees of PT. Smartfren Jember is done well and is able to provide direction for career development so it emerges good behavior for employees: 4) Organizational commitment has a positive effect through OCB on employees of PT. Smartfren Jember. This is due to the organizational commitment of employees of PT. Smartfren Jember is done well and improves OCB; 5) Job satisfaction, organizational culture, motivation, organizational commitment simultaneously have a positive effect through OCB on employees of PT. Smartfren Jember.

\section{Refrences}

Aidla, Anne dan Vadi, Maaja.2003. Relationships Between Organizational Culture And Performance In Estonian Schools With Regard To Their Size And Location. Thesis.Tartu University

Aiyetan, A 0 and Olotuah, A 0, 2006, Impact of motivation on workers' productivity in the Nigerian construction industry. In: Boyd, D (Ed) Procs 22nd Annual ARCOM Conference, Birmingham, UK, Association of Researchers in Construction Management, 239-248

Alotaibi, A. G. 2001. Antecendents of OCB: A study of public personnel in Kuwait. Public Personnel Management. Vol. 30, No. 3.

Anwar Ali Shah G. Syed dkk, 2012, Motivation as a Tool for Effective Staff Productivity in the Public Sector: A Case Study of Raw Materials Research and Development Council of Nigeria, Asian Social Science, Vol. 8, No. 11

Chaudhary, N dan Sharma, B, 2012, Impact of Employee Motivation on Performance (Productivity) In Private Organization, International Journal of Business Trends and Technology, volume2, Issue 4 
Darufitri, K. 2002. "Pengaruh Motivasi, Iklim Organisasi, EQ dan IQ Terhadap Kinerja Karyawan: Studi Kasus DPU dan Setda Kabupaten Bantul." Sinergi, Vo.4, No.2, Hal.41-48.

Diadjeng Laraswati Hanindyani. 2008. Pengaruh sikap dan kecerdasan emosi terhadap organizational citizenship behaviour (OCB) karyawan di badan pengkajian dan penerapan teknologi (periode: April - Mei 2008). Tesis, UI.

Dyne, Linn Van, Graham, Jill W., dan Dienesch, Richard M. 1994. Organizational Citizenships Behavior: Construct Redefinition, Measurement, and Validation. Academy of Management Journal, Vol. 37, 765-802.

Georgellis, Y., dan Lange, T., 2007. Participation In Continuous, On-The-Job Training And The Impact On Job Satisfaction: Longitudinal Evidence From The German Labour Market. International Journal of Human Resource Management. vol.18

Ghozali, I. 2002. Aplikasi Analisis Multivariat dengan Program SPSS. Badan Penerbit Undip. Semarang.

Hashim ZAMEER dkk, 2014, The Impact of the Motivation on the Employee's Performance in Beverage Industry of Pakistan, International Journal of Academic Research in Accounting, Finance and Management Sciences, Vol.4, No.1, pp.293-298

Kodjo Ezane Joseph, Changjun Dai, 2009, The influence of organisational culture on organizational learning, worker involvement and Worker Productivity, International juournal of business and management,vol4, no.9

Kreitner, Robert dan Kinicki, Angelo, 2003, Perilaku Organisasi, Terjemahan: Erly Suandy, Edisi Pertama, Penerbit Salemba Empat, Jakarta.

Lin, L., Yeh, S., Yang, L., Yang, L., Tseng, C., dan Yeh, M. 2003. Satisfaction Of Nurse Aides With Pre-Job Training Programs. Journal of Nursing Research, 11(2), 101-108

Muogbo U.S, 2013, The Impact of Employee Motivation On Organisational Performance (A Study Of Some Selected Firms In Anambra State Nigeria), The International Journal Of Engineering And Science (IJES), Volume2, Issue7, Pages 70 - 80

Ogbonna, Emmanuel and. Harris, Lloyd C. 2000. Leadership Style, Organizational Culture And Performance: Empirical Evidence From Uk Companies. Int. J. Of Human Resource Management 11:4 August 2000 766-788

Podsakoff, P. M., MacKenzie, S. B., Paine, J. B., dan Bachrach, D. G. 2000. Organizational Citizenship Behaviors: A critical review of the theoretical and empirical literature and suggestions for future research. Journal of Management, 26(3), 513-563.

Robbins, Stephen P, 2006, Perilaku Organisasi. Edisi kesepuluh, Jakarta: PT Indeks Kelompok Gramedia

Shahzad, Fakhar, Zahid Iqba, Muhammad Gulzar, 2013, Impact of Organizational Culture on Employees Job Performance: An Empirical Study of Software Houses in Pakistan, Journal of Business Studies Quarterly, Volume 5, Number 2

Sokro, Evans. 2012, Analysis Of The Relationship That Exists Between Organisational Culture, Motivation And Performance, Jurnal Problem Of Management In The 21st Century Vol. 3 P106

Tika, M. Pabundu. 2008. Budaya Organisasi dan peningkatan kinerja perusahaan. Cetakan kedua. PT. Bumi Aksara. Jakarta

Tokasi, Neda, Kojori, Davood Kia, Fereidouni, Nasere, 2014, The relationship between organizational culture, entrepreneurship culture, and job motivation with productivity of teachers working in Ramsar schools in academic year 2012-2013, International Journal of Scientific Management dan Development;Jun2014, Vol. 2 Issue 6, p198

Wibowo, 2010. Budaya organisasi, Sebuah kebutuhan untuk meningkatkan kinerja jangka panjang. Cetakan ke-1. Rajawali Pers. Jakarta.

Zameer, Hashim, 2014, The Impact of the Motivation on the Employee's Performance in Beverage Industry of Pakistan, International Journal of Academic Research in Accounting, Finance and Management Sciences, Vol.4, No.1, pp.293-298 